\title{
Digital Processing of Blood Cells Using Matlab
}

\author{
Nunik Destria Arianti ${ }^{1}$, Azah Kamilah Muda ${ }^{2}$, Norashikin Ahmad ${ }^{3}$, Neny Rosmawarni ${ }^{4}$, \\ Fitri Ramasita ${ }^{5}$ \\ \{P031810028@student.utem.edu.my11,azah@utem.edu.my², norashikin@utem.edu.my ${ }^{3}$, \\ neny@istn.ac.id ${ }^{4}$, ramasitafitri@gmail.com ${ }^{5}$ \} \\ Universiti Teknikal Malaysia Melaka, 75450 Melaka, Malaysia ${ }^{1,2,3,4}$ \\ Department of Information System, Nusa Putra University, Sukabumi, Indonesia ${ }^{1}$ \\ Department of Information Technology, National Institute of Science and Technology, Indonesia ${ }^{4,5}$
}

\begin{abstract}
At present, the process of separating normal and abnormal red blood cells was carried out through laboratory testing, which often requires a lot of time and cost. Therefore, this paper presents an abnormal red blood cell detection scheme to make it easier to diagnose a disease, speed up the identification process so that it saves time and money. Because without having to go through a chemical process, which processes one by one so that it slows down the time of identification and uses high costs, the method proposed in this paper was to calculate the number of normal and abnormal blood cell objects using the digital image processing method using Matlab. This study could not only determine normal and abnormal blood cells using a feature extraction method based on shape. The impact of this study was to create a system to separate blood cells that have collided before the process of detecting the form and calculation of the number of normal and abnormal red blood cell objects in an image of a blood cell.
\end{abstract}

Keywords: Blood Cells, Image Processing, Mathlab.

\section{Introduction}

Blood is a liquid that is very important for humans because it functions as a means of transportation of substances, such as oxygen, body metabolic products, the body's defense against germs, regulating acid-base balance, and has many other uses to support life. Health services for patients are required to have the ability to diagnose diseases based on complaints data, physical examination and medical support. But the doctor has limitations in remembering the disease from complaints, the results of physical examination and medical supporting data and limitations in remembering therapy and actions that must be given to patients. To assist the doctor's assignment, an information system is needed that can help the doctor confirm the diagnosis of the disease and provide accurate treatment. Image processing technology has a very wide application in various fields of life. In the field of medicine, image processing technology makes it easy to diagnose an illness, speed up the identification process so that it saves time and money. Because without having to go through a chemical process, which processes one by one so it slows down the time of identification and uses large costs. 


\section{Literature Review}

\subsection{Blood Cell Identification Technique}

The pathology department is a department in the medical world that handles blood problems. Identifying blood cells in a person are usually needed to find out or diagnose a disease that might be suffered. At present the time needed by pathologists to identify a person's blood cells requires an average of up to 7 days or even beyond that time, causing patients to start treatment late, this should not occur in patients with high-risk diseases. Therefore, we need a system that can support this case so that the identification of blood cells does not require a long time and does not require expensive costs. In this study, we will discuss computerized blood cell identification using the image processing approach.

Identification of blood cells is very important for patients who are likely to suffer from highrisk diseases, now the patient's waiting time in receiving the results of the examination is relatively long because the examination carried out by pathologists is manual so that it can inhibit the treatment [1][2][3]. The red cell classification process has two phases: the first separates red blood cells in normal and abnormal types and the second classifies abnormally in three subclasses. The algorithm proposed for classification of red blood cells in normal and abnormal It has three main modules: Preprocessing module, Calculation module, and Classification module (Classification I and II) and 11 operations are carried out in MATLAB [4]. In the process of detecting and identifying blood cells, namely in the segmentation of red blood cells and white blood cells using a color space model with the help of MATLAB software getting $87 \%$ accuracy [1]. In 2015 chan et al. Developing a portable and affordable automatic cell counting device that enables rapid diagnosis that can do complete blood counts, so patients or even healthy people can check their blood count regularly and identify possible diseases before it's too late, Internet-of-Things (IoT) and MATLAB is used in making the tool [2], in this case the MATLAB method also plays a role in the identification of blood cells [5][6].

In its development, many techniques, approaches and methods are used in the detection and segmentation of blood cells. The K-Mean clustering method can also be used in automatic blood cell segmentation. In addition to blood cell segmentation, this method can also be used in preprocessing, segmentation, overlapping blood cell separation and evaluation of segmentation results and segmentation accuracy achieved in $98.89 \%$ [7], Fuzzy methods can also be used in the case of identification of blood cells [8].

Otsu's approach can also be used in the segmentation of white blood cells. Wu et al. Making a New Color Image Segmentation Method and Its Application to Image Analysis of White Blood Cells using the Otsu approach, The results of the experiment show that this method works successfully in the segmentation of color smear microscopic images, this method is successful in segmenting white blood cell images. Sel dan inti diterapkan secara efektif, tetapi juga memiliki kelemahan segmentasi terlalu banyak tergantung pada efek dari metode pewarnaan dan bentuk inti tidak terlalu baik [9][10][11].

In the classification of normal and abnormal red blood cells, the method of Artificial Neural Network (ANN) classifier can also be used. In this case it functions to automate the process of detection and identification of red blood cells from the image of blood smear $[12][13][14][15][16]$.

This study proposes a computerized system, explaining how to calculate the number of normal and abnormal blood cell objects using the digital image processing method using Matlab, which aims to create a system that has the function of separating previously collided blood cells by detecting the shape and calculation of the number of red blood cell objects normal and 
abnormal images of a blood cell. Whereas in a previous study by Nicoleta Safca, et al, who was conducted in 2018 with the title Image Processing Techniques to Identify Red Blood Cells, the study presented a method for automatic identification and classification of red blood cells in various interest classes for diagnosis using microscopic images of blood smears, Using this information, several factors (form factors, circularity factors and deviation factors) involved in the classification of red blood cells are calculated.

From the literature review above the accuracy of the identification results is a big challenge that must be solved because this case is related to the survival of a person, where the results of this identification become a benchmark for anyone making a decision to carry out treatment. In addition to the accuracy of the results of the time in the examination and the results received by the patient must also be an equally important calculation so that patients can make decisions in determining the treatment for what they suffer.

\section{Materials and Methods}

The classification process of blood cells has two phases: the first separates red blood cells, white blood cells and blood plasma then calculates each number of blood cells in normal and abnormal types and the second classifies abnormally in three subclasses. The algorithm proposed for the classification of normal and abnormal blood cell counts is presented in the Fig. 1. It has Four main modules: pre-processing module, image segmentation, calculation module, total cell number, and classification module.

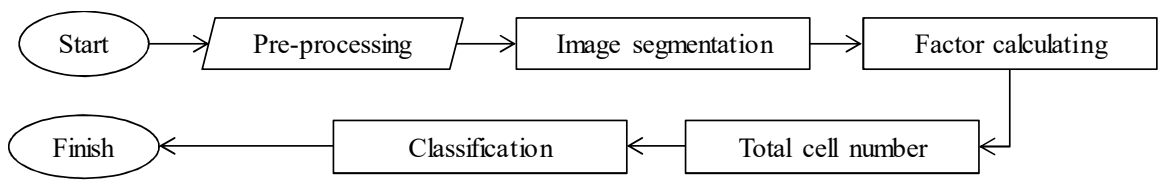

Fig. 1 Proposed method for red cell classification

\subsection{PreProcessing}

The first step in this proposed method is preprocessing the image is read image. Then convert RGB images to grayscale images and contrast enhancements. Finally, it labeling every object found.

\subsection{Image Segmentation}

At this stage, the red blood cells are separated from white blood cells, platelets and blood plasma. This separation is done by looking at the difference in color, shape and size of the four types of blood cells. It is expected that after this process the analysis and calculation of blood cells will be easier. The target of the output of this process is the image of red blood cells only and will be a benchmark in determining the classification of blood cells studied. 


\subsection{Factor Calculating}

The next step in the proposed method is calculating each factor necessary for the algorithm using the features extracted. Features extracted that can be used in the form of circularity factor, form factor, deviation factor and semilunarity factors like that done by Safca et al. [19]

\subsection{Clasification}

The process of classification of blood cells in this case we will emphasize just one of the blood cells as an object of red blood cells are carried out using the factors described above. The classification process can be seen in the Fig. 2. First, we classify cells in two categories, namely the normal and abnormal categories based on the number of blood cells contained in $1 \mathrm{~mm}^{3}$ of blood, which is processed by the separation of blood cells based on color and shape and size. After preprocessing images, Segmentation and calculation factors. Various conditions are set to be the standard of the calculated factor values. The measuring point used is based on biological information and literature review. The classification process, the number of red blood cells is classified in 3 different classes according to the number of red blood cells found in $1 \mathrm{~mm}^{3}$ of blood cells, which is less than the number of standard cells, according to the number of standard cells or more than the number of standard cells. If the number of red blood cells, according to the standard number is categorized as normal, but if the number of red blood cells is stated to be less or more than the standard number of red blood cells, then it is declared abnormal. This classification is also done using image processing techniques and thresholding.

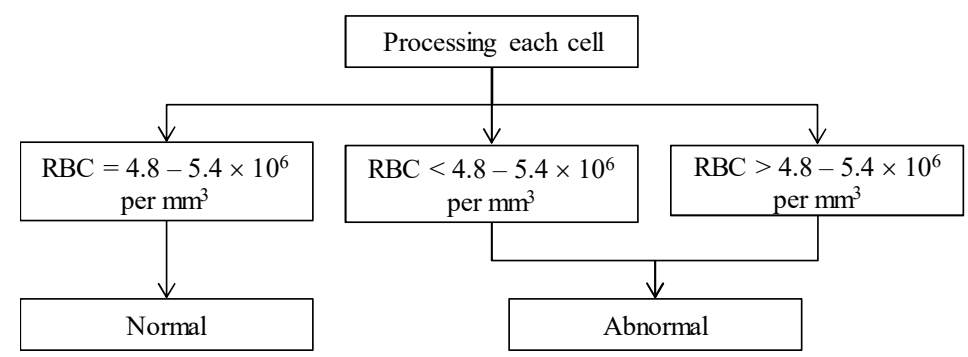

Fig. 2 Classification process I

\subsection{Characteristics of Human Red Blood cells}

The component of human blood is presented in Fig. 3. There are four types of cells in human blood, which are numbered, as mentioned in Table 1 for healthy humans. The proportion of the four parts of the blood cell are :

a. Count the number of red blood cells. The number of red blood cells contained in $1 \mathrm{~mm}^{3}$ of blood is $45 \%$. RBC $=4.8-5.4 \times 10^{6}$ per $\mathrm{mm}^{3}$.

b. Count the number of white blood cells. The number of red blood cells contained in $1 \mathrm{~mm}^{3}$ of blood is less than $1 \%$. WBC $=4-11 \times 10^{3}$ per $\mathrm{mm}^{3}$.

c. Calculate platelet counts. The platelet count contained in $1 \mathrm{~mm}^{3}$ of blood is less than $1 \%$. Platelet $=2-5 \times 10^{5}$ per $\mathrm{mm}^{3}$. 
Table 1 Normal Blood Cell Count

\begin{tabular}{|l|r|r|r|}
\hline \multicolumn{1}{|c|}{ Cell type } & Total amount (cell/ml) & Calculate the cell $\left(\right.$ cell/ mm $\left.\mathbf{~ m}^{\mathbf{3}}\right)$ & Average (normal) \\
\hline Red Blood Cell (RBC) & $5,000,000,000$ & $5,000,000$ & $4.8-5.4 \times 106$ \\
\hline White Blood Cell (WBC) & $7,000,000$ & 7,000 & $4,000-11,000$ \\
\hline $\begin{array}{l}\text { Count the Type } \\
\text { (defferencial count) WBC }\end{array}$ & \multicolumn{3}{|c|}{ Neotrofil 60 - 70 \%; Monosit 2-6\% } \\
\hline Platelet & Eosinofil 1-4 \%; Limfosit 25-33\%; Basofil $0.25-0.5 \%$ \\
\hline
\end{tabular}

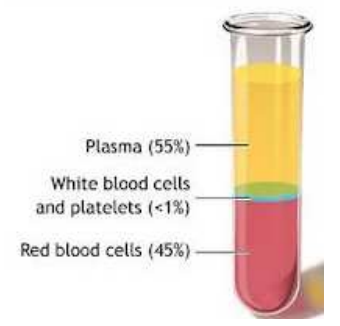

Fig. 3.component of human blood

\section{Experimental Result}

In accordance with the title above all calculations are performed using MATLAB. One image sample (Fig 4.a) that will be processed in this case will be taken as an example of a blood cell of a leukemia sufferer. The first step in preprocessing is applied to microscopic images. The image used is a 2D image that will be processed first making the image become gray, then increasing contrast, and turning the image into a binary process. The image used was taken from the American Society of Hematology Image Bank following the paper of its predecessor.

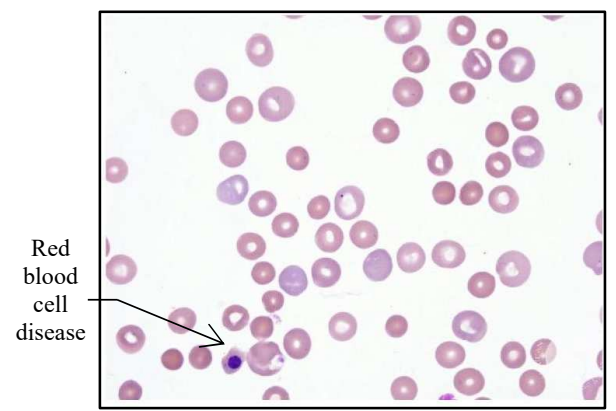

(a)

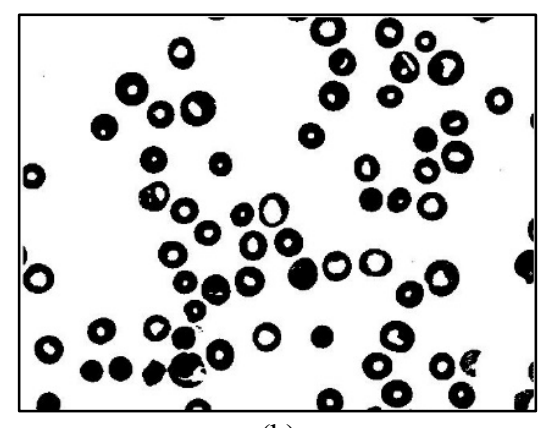

(b)

Fig. 4 First step of preprocessing: a) original image, b) gray scale image

Basically, the color used in grayscale is black as a minimum color (0), and white (255) as the maximum color, so the color between them is gray (Fig 4.b). The degree of gray itself has a value, not only a scale of 0 to 255. It depends on the pixel value of the image. Gray scale (grayscale $=\mathrm{G}$ ) is divided into a number of levels, has a value in the form of an integer and is the result of the departure of two. $G=2 \mathrm{~m}$ [17]. The binarization process converts vulnerable 
images to 0 (black) and 1 (white). The shape and structure of an object in the image generally affects the operation of morphological imaging. Binary image processing The goal is to filter.

Experiments to be carried out will take samples to detect the number of red blood cells based on patients with Howell Jolly Body abnormalities, in this case we will only examine red blood cells, the characteristics of red blood cells are as follows: Red blood cells have a disk size of 7.5 $\mu \mathrm{m}$ with an edge thickness of $2 \mu \mathrm{m}$. The center of the chakra is thinner with a thickness of $1 \mu \mathrm{m}$. This interesting biconcave form accelerates gas exchange between cells and blood plasma [18].

In this paper, overlapping cells are removed differently from their predecessor journals which do not eliminate overlapping cells because they are considered important for the analysis carried out. Labeling objects from images is done by using the "bwlabel" function just like its predecessor journal. Each object must be identified and labeled to develop the algorithm. In Fig. 5 presented the process by which red cells are separated from the background of the image and has been processed in binary images.

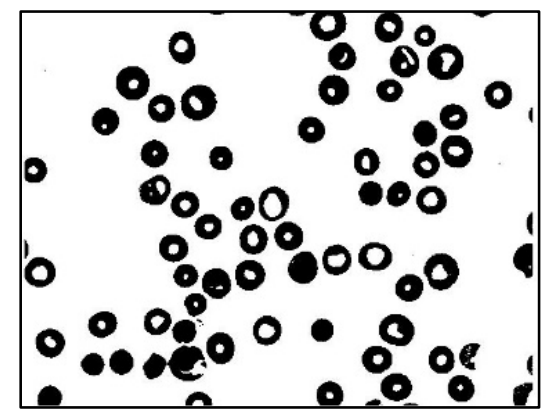

Fig. 5 Binary image from cells

An "imfill" function is then used to process the binary image (Fig. 5) to Fig. 6.a. In the case of this image, the hole in the image object is a set of pixels that represent impressive pixels that are not accessible to the background on the edge of the image. Furthermore, to separate one cell with another cell because it is close together, a function "watershed" is used to separate the two cells. This function works by giving a smooth shape whose color is like the background of an image in each basin between two red blood cells.

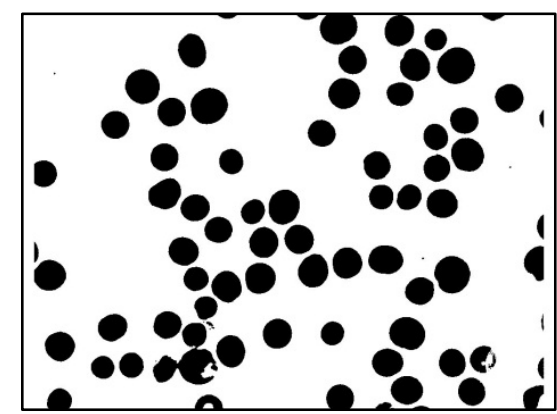

(a)

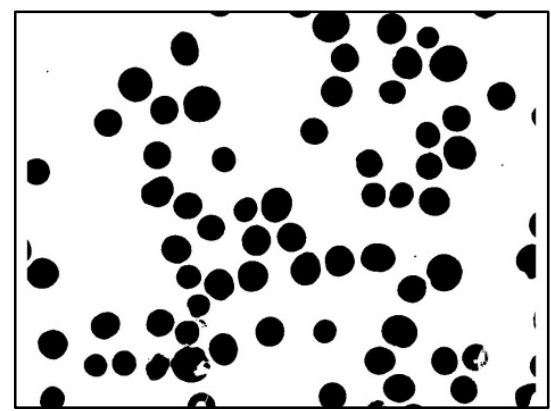

(b)

Fig. 6 Morphological operations (a) filled holes (b) watershed 
In this study, the calculated feature was the feature of diseased red blood cells. The gray image results are converted into binary imagery using adaptive thresholding. Adaptive thresholding is used to overcome the image, which is possible to have a different threshold value. The difference in threshold value is due to noise, such as light and shadow. Adaptive thresholding is used to separate the foreground and background. In this study, the front is an abnormal red blood cell, which is represented by a number 0 in black. Meanwhile, the background is an area other than diseased red blood cells represented by number 1 with white. The results of a binary image of ill red blood cells using adaptive thresholding are shown in Fig. 7.a.

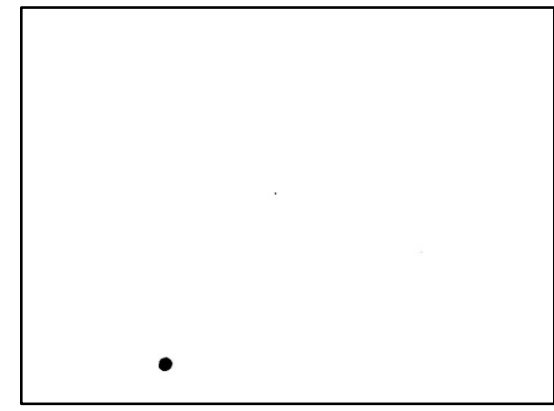

(a)

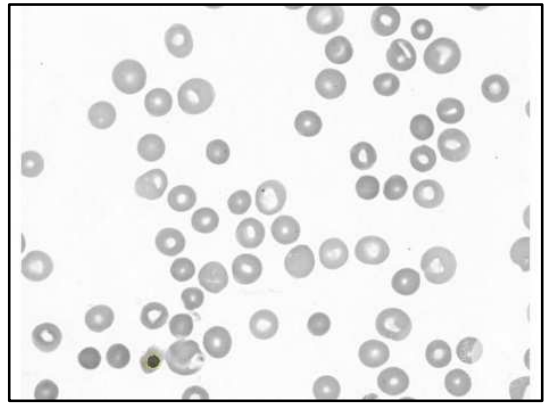

(b)

Fig. 7 The process of extracting abnormal red blood cells (a) threshold (b) overlaying and cell labeling results in abnormal red blood cell threshold with a grayscale image

The classification using this method to predict abnormal red blood cells has been successful. From the images analyzed, it was found that there were 61 red blood cells with one of them being abnormal red blood cells. Abnormal red blood cells can be distinguished from normal blood cells properly. This method shows the results of reasonable accuracy like the results of previous studies [19-21].

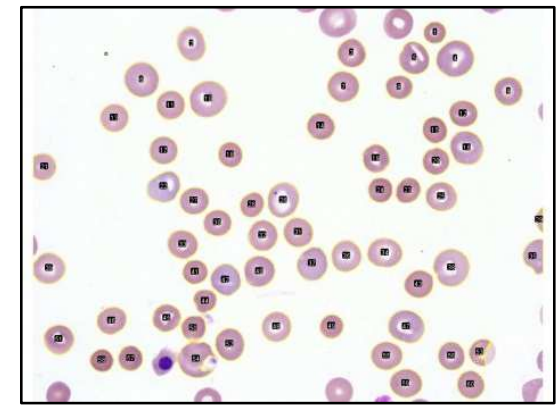

(a)

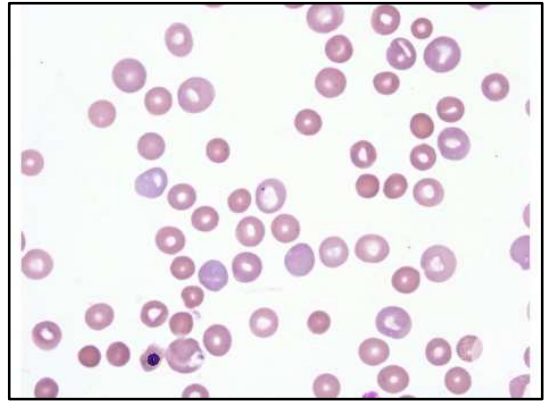

(b)

Fig. 8 Classification results (a) borders and counting normal red blood cells (b) borders and abnormal blood cell counting 


\section{Conclusions}

Digital processing of blood cells using Matlab has been conducted and described in this paper. Image processing based algorithms have been applied to images in which normal and abnormal red blood cells are present. Identification, classification, labeling, and counting of these cells has also been successfully carried out with reasonable accuracy. The method developed was not intended to replace pathologists, but to help it improve the testing of image samples with various forms of red blood cell combinations to be able to assess the performance of the algorithms developed. The future work from this research was to do more testing of image samples with various forms of combinations of red blood cells to be able to assess the performance of the algorithms developed.

\section{References}

[1] M. Bhatt and S. Prabha, "Detection of Abnormal Blood Cells Using Image Processing Technique," vol. 07 , no. 01, pp. 89-94, 2015.

[2] Z. H. Chan et al., "Cellco: Portable Device for Automated Blood Cell Count and Abnormal Cell Detection," J. Telecommun. Electron. Comput. Eng., vol. 9, no. 3, pp. 119-122, 2015.

[3] A. Jaume-i-Capó, C. Mena-Barco, and B. Moyà-Alcover, "Analysis of Blood Cell Morphology in touch-based devices using a CAPTCHA," pp. 1-2, 2016.

[4] R. B. Cells, "Image Processing Techniques to Identify," 2018 22nd Int. Conf. Syst. Theory, Control Comput., pp. 93-98, 2018.

[5] Y. Ma, R. Dai, and L. Li, "A counting and segmentation method of blood cell image with logical and morphological feature of cell," Chinese J. Electron., vol. 11, no. 1, pp. 53-55, 2002.

[6] M. M. A. Mohamed and B. Far, "A fast technique for white blood cells nuclei automatic segmentation based on gram-schmidt orthogonalization," Proc. - Int. Conf. Tools with Artif. Intell. ICTAI, vol. 1, pp. 947-952, 2012.

[7] S. S. Savkare, A. S. Narote, and S. P. Narote, "Automatic Blood Cell Segmentation Using K-Mean Clustering from Microscopic Thin Blood Images," pp. 8-11, 2016.

[8] M. S. Lan and S. Abe, "A Neural-Network-Based Fuzzy Classifier," IEEE Trans. Syst. Man Cybern., vol. 25, no. 2, pp. 353-361, 1995.

[9] J. Wu, P. Zeng, Y. Zhou, and C. Olivier, "A novel color image segmentation method and its application to white blood cell image analysis," Int. Conf. Signal Process. Proceedings, ICSP, vol. 2, pp. 4-7, 2007.

[10] I. Cseke, "A fast segmentation scheme for white blood cell images," Proc. - Int. Conf. Pattern Recognit., vol. 3, pp. 530-533, 1992.

[11] Y. Chen, D. R. Chen, Y. Li, and L. Chen, "Otsu's thresholding method based on gray level-gradient two-dimensional histogram," CAR 2010 - 2010 2nd Int. Asia Conf. Informatics Control. Autom. Robot., vol. 3, pp. 282-285, 2010.

[12] F. M. Nor, M. M. A. Jamil, N. F. N. Fuad, R. Tomari, and W. N. W. Zakaria, "Computer Aided System for Red Blood Cell Classification in Blood Smear Image," Procedia Comput. Sci., vol. 42, pp. 206-213, 2014.

[13] H. Sheikh, Bin Zhu, and E. Micheli-Tzanakou, "Blood cell identification using neural networks," vol. 1751, pp. 119-120, 2002.

[14] M. Habibzadeh, A. Krzyzak, and T. Fevens, "White blood cell differential counts using convolutional neural networks for low resolution images," Lect. Notes Comput. Sci. (including Subser. Lect. Notes Artif. Intell. Lect. Notes Bioinformatics), vol. 7895 LNAI, no. PART 2, pp. 263-274, 2013.

[15] B. Swolin, P. Simonsson, S. Backman, I. Löfqvist, I. Bredin, and M. Johnsson, "Differential counting of blood leukocytes using automated microscopy and a decision support system based on artificial neural 
networks - Evaluation of DiffMaster ${ }^{\mathrm{TM}}$ Octavia," Clin. Lab. Haematol., vol. 25, no. 3, pp. 139-147, 2003. [16] Y. Hirimutugoda and G. Wijayarathna, "Image Analysis System for Detection of Red Cell Disorders Using Artificial Neural Networks," Sri Lanka J. Bio-Medical Informatics, vol. 1, no. 1, p. 35, 2010.

[17] T. M. Kuliah and A. D. Pahrany, "Laporan Pemrosesan Citra Digital Pemrosesan Citra Digital Citra analog Citra Citra Digital Matriks 2 dimensi yg terdiri dari angka- angka Masing-masing pixel menunjukkan tingkat kecerahan," 2015.

[18] S. Penghitungan, J. Sel, D. Merah, D. Hartadi, and R. R. Isnanto, "Simulasi penghitungan jumlah sel darah merah," pp. 1-6.

[19] Safca, N., Popescu, D., Ichim, L., Elkhatib, H., \& Chenaru, O. (2018, October). Image Processing Techniques to Identify Red Blood Cells. In 2018 22nd International Conference on System Theory, Control and Computing (ICSTCC) (pp. 93-98). IEEE.

[20] N. H. Mahmood, and M. A. Mansor, "Red blood cell estimation using hough transform technique," Int. J. Signal and Image Processing (SIPIJ), vol. 3, no. 2, April 2012. Y. Alomari, S.N.H.S. Abdullah.

[21] R.Z. Azma, and K. Omar, "Automatic detection and quantification of WBCS and RBCS using iterative structured circle detection algorithm", Comput Math Methods Med.2014. 